\title{
Law wars: the patient menace
}

\section{Ben Therenbach}

Oh bollocks. Now patients have a legal right to register with me. So no more sympathetic 'TV doctor' facial expressions explaining that because they live outside our catchment area I'm really sorry but you can't come and grace us with your nasty problems.

In recent years schools have made this method of discrimination easy for us. They started it - to coin a playground explanation - by introducing catchment areas. The schools justify it because there are only so many students that can be accommodated, taught, and looked after safely. Likewise in general practice there are only so many patients that I can seat in the waiting room, tolerate, and fool that I care.

Years ago during my turbulent hormone years as the oldest child in our family I had to fight for the right to get some sex education - to stay up and watch Pan's People on Top of the Pops, to go into town without my parents, and drink shandy. But my younger siblings, they got to do all of these things without any battles. Similarly, schools have taken the flack whilst establishing this as 'the way it is', so we in general practice have been able to allege catchment areas and nobody questions it.

But they're bloody well going to question it now, aren't they? We're right back to the years of the last century and that damned 'Patients Charter'. Back then it was constant leaflet waving, demanding antibiotics, unnecessary home visits, and middle-of-the-night calls "because it's my right". At least back then those of us with balls (metaphorically speaking) fired back with 'Your Responsibilities' until impotent health authorities found out about this and hypocritically said that wasn't fair. Now the legal right to register anywhere means we won't have a chance to fight back. Or will we?

Everyone is jumping on the 'choice' bandwagon. Choose and Book now gives patients a choice of where they are seen. Ironically this choice has always been available but in reality now the choice is actually less than ever. Even family planning experts are campaigning for more choice for their users with this lark about LARCs. So I'm going to give my patients choice too.

You can come and register with me wherever you're from. Just be aware that you may have to wait weeks for an appointment, or if you use the 48-hour service we offer you'd better be ready to call in using at least three phones because you've more chance of getting through on a national radio competition line, or to the Department of Health for that matter, than you have of getting through to us: despite now offering sixteen or more lines it's still only Beryl and Gladys from the 'Return to Work After Retirement' scheme at the end of them. They're the only ones willing to tolerate the abuse we get from patients who say: "Do you know how far I've had to come to see this doctor? What do you mean I'm going to have to wait?"

Yes, we might quickly become overloaded because we're such a good practice, but we can use this to our advantage. Not only financially, but as self-promotion. With a packed waiting room we'll be seen as desirable, promoting our practice as 'a good product'. It also means

J Fam Plann Reprod Health Care 2008; 34(4): 267

Faulty Powers Surgery, Lorsanass, UK

Ben Therenbach, MRCGP, General Practitioner patients learn they'll have to wait so they won't complain. That reminds me, I'll need to create something else for patients to complain about because I know how much Beryl and Gladys enjoy some verbal 'argy-bargy' over the reception desk.

One possible problem is the further away patients live, the more likely they are to be late for an appointment. I know this because it can take 30 minutes for me to travel a mile and half in commuter traffic. This is really going to upset my midday siesta because if they arrive late I'll run later than ever. But hang on, I'm seeing a solution. Yes, let them register from far and wide, as far away as possible. Because we have a policy that if you're later than 15 minutes for your appointment you get DNA'd. So in theory I wouldn't have to see any patients at all, because they'd all be late.

So far so good. But inevitably the PCT will become wise to this. Well, we'll please our masters by booking patients in from 6 am or 7 am as has been suggested by the Government. Extended access it's called, isn't it? But patients won't get to us until 9 am, so everybody is happy. We're offering extended hours, patients can book appointments that are convenient to them, I get to stay in bed as I always used to, and the Department of Health can shift the blame onto the Department of Transport.

This is working out fine. We could also set up a B\&B facility in the upper floor of the practice so people can stay overnight and be seen the following day - after all, it's trendy to have all services under one roof. We'll have a condom on the pillow rather than a chocolate in the executive rooms thereby nailing the safer sex and healthy eating messages in one go. For those in the dorms we'll be able to offer emergency contraception within 12 hours for maximum effectiveness. And no, this won't interfere with my respectable 9 am start. I'll do what any self-respecting British B\&B does and only offer breakfast between 8 and $8.15 \mathrm{am}$, so the patient's bowels being woken up will prevent anyone arriving before $8.45 \mathrm{am}$. If that's not enough, the cooked breakfast means my nurses get away without seeing so many patients because "Oh I'm sorry, but you need to be fasting for this blood test".

Good, all that time I've spent perfecting my sympathetic 'TV doctor' facial expression won't be wasted after all.

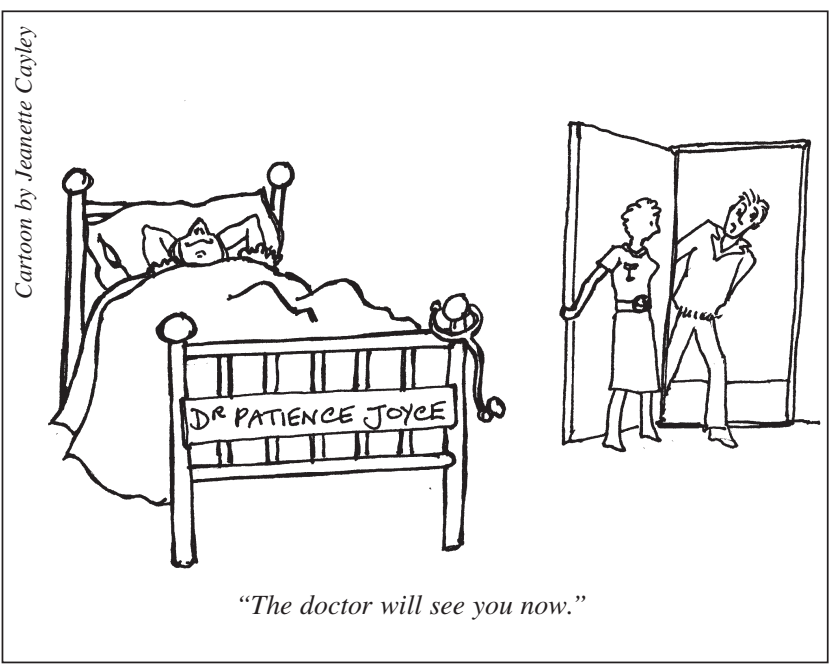

